\title{
RELIGIOUS SELF-REGULATION: THE MEANS OF PSYCHODIAGNOSTICS AND THE ROLE IN WELL-BEING
}

\section{Kuznetsov O. I.}

\section{INTRODUCTION}

The problem of psychodiagnostics of religious self-regulation seems particularly relevant in connection with the need to provide psychological well-being. As indicated in the study of M. McCullough \& B. Willoughby religiousness is significantly associated with psychological well-being ${ }^{1}$. In a meta-analytic review of 147 independent effect sizes, T. Smith, M. McCullough, and J. Poll $^{2}$ found that religiousness (measured in a wide variety of ways) was associated with lower rates of depressive symptoms. Moreover, this overall mean effect size obscures the fact that some measures of religiousness (e.g., positive religious coping and intrinsic religious motivation) had even stronger negative correlations with depressive symptoms, whereas measures of negative religious coping and extrinsic religious motivation were positively related to depressive symptoms ${ }^{3}$.

Similarly, in a meta-analysis prepared by R. Witter, W. Stock, M. Okun, \& M. Haring ${ }^{4}$ it was concluded that religiousness has positive correlations with subjective well-being. A more recent meta-analytic review conducted by G. Ano \& E. Vasconcelles ${ }^{5}$ also concluded that «positive» forms of religious coping were positively associated with

1 McCullough, M. E., Willoughby, B.L.B. Religion, Self-Regulation, and SelfControl: Associations, Explanations, and Implications. Psychological Bulletin. 2009. 135, pp. 69-93. doi: 10.1037/a0014213

${ }^{2}$ Smith, T. B., McCullough, M. E., Poll, J. Religiousness and depression: Evidence for a main effect and the moderating influence of stressful life events. Psychological Bulletin, 2003. 129. Pp. 614-636.

${ }^{3}$ McCullough, M. E., Willoughby, B.L.B. Religion, Self-Regulation, and SelfControl: Associations, Explanations, and Implications. Psychological Bulletin. 2009. 135. Pp. 69-93. doi: 10.1037/a0014213

${ }^{4}$ Witter, R. A., Stock, W. A., Okun, M. A., Haring, M. J. Religion and subjective well-being in adulthood: A quantitative synthesis. Review of Religious Research, 1985. 26, pp. 332-342.

${ }^{5}$ Ano, G. G., Vasconcelles, E. B. Religious Coping and Psychological Adjustment to Stress: A Meta-Analysis. Journal of Clinical Psychology, 2005. 61. Pp. 461-480. 
scores on measures of positive psychological outcomes, such as satisfaction with life and happiness, and negatively related to negative outcomes, such as anxiety and depression.

\section{Religious orientations and self-regulation: an approach to the problem}

The notion of religious orientations has its roots in the pioneering work of G. Allport ${ }^{6}$ and attempts to clarify different ways in which religious people express, experience, and motivate their religiosity. G. Allport distinguished between two basic orientations which he characterised as intrinsic religiosity and as extrinsic religiosity. According to G. Allport, an extrinsic religious orientation is largely utilitarian, useful for granting safety, social standing, solace and social support. An intrinsic religious orientation, on the other hand, regards faith as a supreme value in its own right, infusing the whole of life with distinctive purpose and meaning. To these two established religious orientations, C. Batson ${ }^{7}$ and C. Batson and W. Ventis ${ }^{8}$ added a third orientation which they characterized as quest religiosity. According to C. Batson, a quest religious orientation embraces complexity, doubt, tentativeness, and honesty in facing existential questions. People with this orientation treat their religion not as a means or an end, but a search for truth. As Batson said, «An individual who approaches religion in this way recognizes that he or she does not know, and probably never will know, the final truth about such matters. Still the questions are deemed important, and however tentative and subject to changes, answers are sought» ${ }^{9}$.

The extrinsically religious person uses religion as a means to another end, whereas the intrinsically religious person holds religion as an ultimate goal. People with an extrinsic motivation use religion for their own ends, whether those ends are hedonic (e.g., social contacts, distraction) or utilitarian (e.g., personal status, business interest), to serve

${ }^{6}$ Allport, G. W. Religious context of prejudice. Journal for the Scientific Study of Religion, 1966. 5. Pp. 447-457.

7 Batson, C. D. Religion as prosocial: Agent or double agent? Journal for the Scientific Study of Religion, 1976. 15. Pp. 29-45.

${ }^{8}$ Batson, C. D., Ventis, W. L. The religious experience: A social psychological perspective. New York: Oxford University Press. 1982. 368 p.

${ }^{9}$ Batson, D. Religion and the Individual. New York: Oxford University Press, 1982. $440 \mathrm{p}$. 
their self-interest rather than acknowledging religious values. People with intrinsic motivations instead regard religious tenets according to their inner value, such that they do not adjust their religious beliefs to their personal interests. Rather, they live the core spirituality of religion and believe in people's intrinsic worth. Extrinsic religion is defined as a means of achieving some self-serving goals, as a tool that promotes social support, comfort and self-esteem, whereas intrinsic religion is defined as being an ultimate goal in itself. Intrinsically motivated people are mainly encouraged by a promise for personal spiritual development and for a deeper, more meaningful relationship with God ${ }^{10,11}$.

According to S. Pace ${ }^{12}$ intrinsic religiosity should invoke a lower degree of value-expressive and social-adjustive attitudes, because these people already meet their need for self-expression through their religiosity, which they use to express their core values and identity.

Nowadays, in the context of a new wave of interest for religiosity (e.g., C. Sedikides ${ }^{13}$, R. Emmons ${ }^{14}$ ), social psychologists have renovated the call for an approach to religiosity not as an undifferentiated and stable phenomenon, but as a more complex experience, which implies a more detailed analysis of the different ways of being religious ${ }^{15}$. In fact, religious people can feel and behave differently in how they live their faith: even among people belonging to the same religious denomination and to the same country, religious values can be internalized in different ways.

During the last decades, several studies have tried to shed light on this multiplicity of ways of «being religious». In particular, an

${ }^{10}$ Hills, P., Francis, L. J., Argyle, M., Jackson, C. J. Primary Personality Trait Correlates of Religious Practice and Orientation. Personality and Individual Differences, 2004. 36. pp. 61-73. http://dx.doi.org/10.1016/S0191-8869(03)00051-5

${ }^{11}$ Hunter, B. D., \& Merrill, R. M. Religious Orientation and Health among Active Older Adults in the United States. Journal of Religion and Health, 2013. 52. Pp. 851-863. http://dx.doi.org/10.1007/s10943-011-9530-4

${ }_{12}$ Pace, S. Effects Of Intrinsic And Extrinsic Religiosity On Attitudes Toward Products: Empirical Evidence Of Value-Expressive And Social-Adjustive Functions. The Journal of Applied Business Research, 2014. 30(4). Pp. 1227-1238.

13 Sedikides, C. Why does religiosity persist? Personality and Social Psychology Review, 2010. 14, pp. 3-6.doi:10.1177/1088868309352323

${ }^{14}$ Emmons, R. A. Religion in the psychology of personality: An introduction. Journal of Personality, 1999. 67, pp. 873-888. doi:10.1111/1467-6494.00076

${ }^{15}$ Pargament, K. I. (2002). The bitter and the sweet: An evaluation of the costs and benefits of religiousness. Psychological Inquiry, 2002. 13, pp. 168-181. doi:10.1207/S15327965PLI1303_02 
interesting analysis of the concept of religious identity derives from selfdetermination theory, which offers a specific conceptualization of the different ways in which values are endorsed. This conceptualization is based on the concept of internalization, which implies that a value can be assumed by the individual with different degrees of autonomy (or self-determination), in a continuum between being endorsed because of external pressure or constriction and being endorsed because it is personally valued, in an independent and autonomous way, that is, a self-determined way ${ }^{16}$.

Within this framework, it is possible to describe two types of internalization of religion that vary in their relative autonomy and, thus, correspond to different degrees of endorsement of religion: introjected internalization and identified internalization. The introjected internalization of religion (religious introjection) represents an adoption of religious behaviors and values which is predominantly based on social pressures and associated with the seeking of approval from oneself and from others. On the opposite side, identified internalization of religion (herein: identification) refers to the adoption of religious values as personal values, personally chosen and valued, that is, a more autonomous and self-determined form of religiosity ${ }^{17}$.

The two types of internalization can also be interpreted as presenting different degrees of «maturity», which are in line with previous research about religiosity. In fact, introjection emphasizes the search for approval, belonging and social recognition, in a way that can be similar to extrinsic religiosity, whereas identification stresses the personal importance of religiosity, as in Allport and Ross' intrinsic scale ${ }^{18}$. Moreover, identification includes some accents of the quest orientation $^{19}$, as it highlights the chance of learning new things provided by religious attendance.

${ }^{16}$ Ryan, R. M., Deci, E. L. Intrinsic and Extrinsic Motivations: Classic Definitions and New Directions. Contemporary Educational Psychology. 2000. 25. Pp. 54-67

${ }^{17}$ Ryan, R. M., Rigby, S., King, K. Two types of religious internalization and their relations to religious orientations and mental health. Journal of Personality and Social Psychology, 1993. 65, pp.586-596.doi:10.1037/0022-3514.65.3.586

${ }^{18}$ Allport, G. W., Ross, J. M. Personal religious orientation and prejudice. Journal of Personality and Social Psychology, 1967. 5, pp. 432-443.

${ }_{19}$ Batson, C. D., Schoenrade, P. A., Ventis, W. L. Religion and the individual: A social psychological perspective. New York, NY: Oxford University Press, 1993. 440 p. 
Self-determination theory considers different ways of activity regulation, the first of them is an intrinsic self-regulation or motivation, which assumes the interest and enjoyment during the activity, on the opposite side there is an extrinsic regulation, which requires the external values of activity.

Intrinsic motivation is defined as the doing of an activity for its inherent satisfactions rather than for some separable consequence. It refers to doing something because it is inherently interesting or enjoyable. When intrinsically motivated a person is moved to act for the fun or challenge entailed rather than because of external prods, pressures, or rewards ${ }^{20}$. According to American research this phenomenon was first acknowledged within experimental studies of animal behavior, where it was discovered that many organisms engage in exploratory, playful, and curiosity-driven behaviors even in the absence of reinforcement or reward ${ }^{21}$. Persons with intrinsic orientation find their master motive in religion. Other needs, strong as they may be, are regarded as of less ultimate significance, and they are, so far as possible, brought into harmony with the religious beliefs and prescriptions. Having embraced a creed the individual endeavors to internalize it and follow it fully. It is in this sense that he lives his religion $^{22}$.

An extrinsic regulation is a second type of self-determined motivation. The extrinsically motivated behaviors are least autonomous and externally regulated. The purest type of extrinsic regulation is external regulation. It satisfies an external demand or obtain an externally imposed reward contingency. External regulation is the type of motivation focused on by operant theorists (Skinnerian theory), and it is external regulation that was typically contrasted with intrinsic motivation in early laboratory and field studies ${ }^{23}$. Individuals with extrinsic orientation are disposed to use religion for their own ends. Thus, external regulation serves other, more ultimate interests, because

${ }^{20}$ Ryan, R. M., Deci, E. L. Intrinsic and Extrinsic Motivations: Classic Definitions and New Directions. Contemporary Educational Psychology. 2000. 25. Pp. 54-67.

21 White R. W. Motivation reconsidered. Psychological Review. 1959. 56. Pp. 297-333.

${ }^{22}$ Allport, G. W., Ross, J. M. Personal religious orientation and prejudice. Journal of Personality and Social Psychology, 1967. 5, pp. 432-443.

${ }^{23}$ Ryan, R. M., Deci, E. L. Intrinsic and Extrinsic Motivations: Classic Definitions and New Directions. Contemporary Educational Psychology. 2000. 25. Pp. 54-67. 
extrinsic values are always instrumental and utilitarian. Persons with this orientation may find religion useful in a variety of ways - to ensure security and solace, sociability and distraction, status and selfjustification. The embraced creed is held lightly or else selectively shaped to fit more primary needs. In theological terms the extrinsic type turns to God, but without turning away from the self ${ }^{24}$.

The third type of religious motivation is introjected regulation, which involves taking in a regulation of activity but not fully accepting it as one's own. Introjection describes a type of internal regulation that is still quite controlling because people perform such actions with the feeling of pressure in order to avoid guilt or anxiety or to achieve egoenhancements or pride. Put differently, introjection represents regulation by contingent self-esteem ${ }^{25}$.

Last form of religious regulation is regulation through identification, which is more autonomous, or self-determined. Identification reflects a conscious valuing of a behavioral goal or regulation, such that the action is accepted or owned as personally important. The person has identified with the personal importance of a behavior and has thus accepted its regulation as his or her own ${ }^{26}$.

The self-determination theory which considers four main forms of self-regulation can be applied to religious activity. According to C. Batson and W. Ventis ${ }^{27}$ we consider the third religious orientation which they characterized as quest religious motive.

According to fig. 1 we consider religious motives for each form of religious orientations and self-regulation: 1) striving for rewards and avoiding punishment from society (external regulation); 2) considering religion as a source of self-esteem maintenance (introjected regulation); 3) considering religion as an important life value (identification); 4) considering religion as a source of truth; 5) considering religion as a source of enjoyment and interest (intrinsic motivation).

24 Hunt S.J. Handbook of Global Contemporary Christianity: Movements, Institutions, and Allegiance (Brill Handbooks on Contemporary Religion) 2016. Brill; Approx. XXXV, $426 \mathrm{p}$.

${ }^{25}$ Ryan, R. M., Deci, E. L. Intrinsic and Extrinsic Motivations: Classic Definitions and New Directions. Contemporary Educational Psychology. 2000. 25. Pp. 54-67.

${ }^{26}$ Ibid.

${ }^{27}$ Batson, C. D., Ventis, W. L. The religious experience: A social psychological perspective. New York: Oxford University Press. 1982. 368 p. 


\section{Religious orientations and self-regulation: results of questionnaire standartization}

The purpose of the research is to determine the possibilities of diagnostics of religious self-regulation and its role in well-being. According to the research aim, the following tasks were set: 1) to analyze psychological approaches to religious self-regulation, orientation and self-regulation and to define religious motives and appropriate items for the scales; 2) to create an original questionnaire of religious self-regulation and check its validity and reliability.

Research methods. The following techniques were used in the study:

In order to create original questionnaire of religious self-regulation items for the scales of New Indices of Religious Orientation (Francis, 2007) and SRQ-R Scale (Ryan, R. M., Rigby, S., \& King, K.,1993) were translated in Ukrainian.

New Indices of Religious Orientation ${ }^{28}$ proposes three nine-item scales of intrinsic religiosity, extrinsic religiosity, and quest religiosity. Each item is scored on a five-point Likert scale.

$S R Q-R$ Scale $^{29}$. This questionnaire concerns the reasons why a person engages in religious behaviors. The questions were written for research with a Christian population, but could be easily adapted for other religions. The questionnaire consists of 12 items and asks why people engage in four religious behaviors, each of which is followed by three reasons. The scale has only two subscales: Introjected Regulation and Identified Regulation.

In order to check the validity of our questionnaire the following scales were used:

The "Psychological analysis of the level of individual religiousness» technique ${ }^{30}$ (authors: I. F. Myagkov, Y. V. Shcherbatykh, M. S. Kravtsova). The questionnaire consists of 40 questions on 8 scales: 1) gnoseological roots of religiousness and tendency to idealistic

${ }^{28}$ Francis, L. J. Introducing the New Indices of Religious Orientation (NIRO): Conceptualisation and measurement. Mental Health, Religion and Culture, 2007. 10, 585-602.

${ }^{29}$ Ryan, R. M., Rigby, S., King, K. Two types of religious internalization and their relations to religious orientations and mental health. Journal of Personality and Social Psychology, 1993. 65, pp.586-596.doi:10.1037/0022-3514.65.3.586

30 Мягков И. Ф., Щербатых Ю. В., Кравцова М. С. Тест «Психологический анализ уровня индивидуальной религиозности». Психологический журнал. 1996. 10, 6. С. $120-122$. 
philosophy; 2) the attitude of the probationer to the magic; 3) the tendency of the personality to seek support and consolation in the religion; 4) external signs of religiousness; 5) interest to so-called «pseudoscience» - mysterious and enigmatic phenomena, in the perception of which belief plays a much greater role than knowledge; 6) the tendency to believe in the Creator and admit the existence of the supreme power that created the universe; 7) the presence of religious consciousness, that is, the internal need in religious belief; 8) the ratio of the subject to religion as a model of moral norms of behavior.

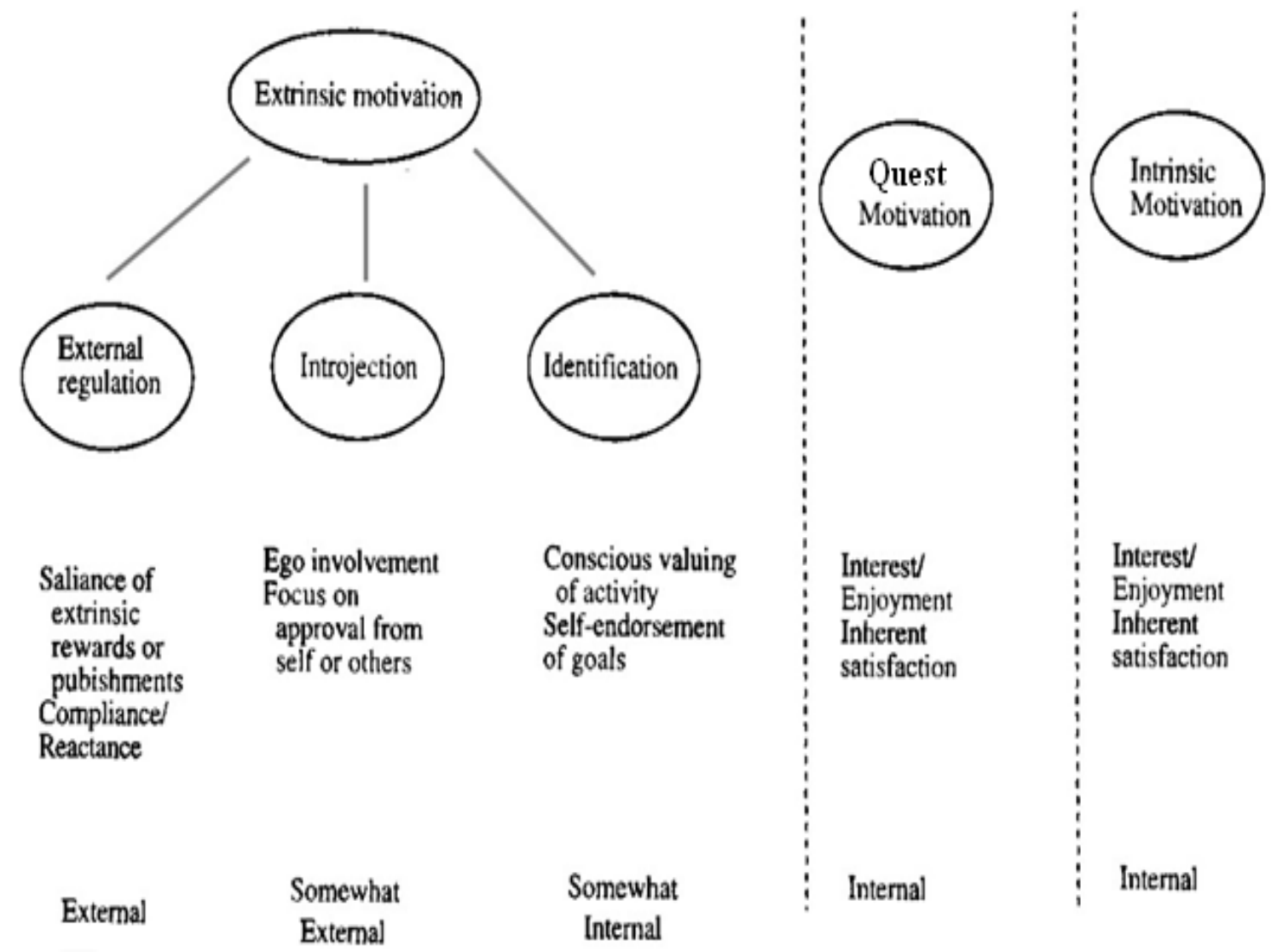

Activity regulation

$\begin{array}{llll}\text { Striving for rewards } & \text { Religion as a source } & \text { Religion is an } & \text { Religion is a search } \\ \text { and avoiding } & \text { of self-esteem } & \text { important life } & \text { of truth } \\ \text { punishment } & \text { maintenance } & \text { value } & \end{array}$

from society

Religious motives

Fig. 1. A taxonomy of human motivation applied to religiosity 
Paranormal belief scale ${ }^{31}$ (authors: J. Tobacyk, in adaptation of D.S. Grigoriev) determines the degree of inclination to irrational thinking and a pseudoscientific explanation of being. The method is presented by 26 statements that make up seven scales: 1) traditional religious faith; 2) belief in psi-ability; 3) belief in witchcraft; 4) prejudice; 5) belief in spiritualism; 6) belief in extraordinary life forms; 7) belief in prophecies.

The spiritual intelligence questionnaire ${ }^{32}$ (author: O.Yu. Holovina). The questionnaire contains 21 items and is represented by 3 scales: 1) the transcendent component of the spiritual intelligence as the ability to self-transcendence, that is, the possibility of expansion of consciousness, achieving its higher states, the ability to intuition as an opportunity to go beyond the rational understanding of life experience, the ability to self-control, allowing to feel the integrity of being; 2) the existential component of the spiritual intelligence as the ability to accept the challenges of life, to solve the problems of existential reality, the ability to search for life's meanings, which are provided by such cognitive properties as objectivity and impartiality of thinking, insight and foresight; 3) the moral component of spiritual intelligence represents the ability to moral self-control and the respectable behavior based on reconsideration of moral values of good and mercy.

Assessment of Beliefs and Behaviors in Coping (original adaptation $)^{33}$. According to the different scientific views to religion as a mean to overcome the stress and to the psychological functions of religion (offering a sense of community, providing a worldview that makes sense of life, allowing for a personal relationship with a higher power, providing overall structure in everyday life) we had chosen «Assessment of Beliefs and Behaviors in Coping" " $^{34}$, translated and adapted it in Ukrainian.

31 Григорьев Д. С. Адаптация и валидизация шкалы веры в паранормальное. Соииальная психология и общество. 2015. 6, 2. С. 132-145.

32 Головіна О. Ю. Застосування опитувальника «Духовний інтелект особистості у вивченні духовності людини. Вісник наџіонального університету оборони України. Збірник наукових праџь. К: НУОУ, 2015. 3(46). С. 64-68.

${ }^{33}$ Kuznetsov O.I. Psychodiagnostics of religious coping strategies Вісник ХНПУ ім. Г.С. Сковороди. Психологія. Харків: ХНПУ, 2017. 57. С. 132-140.

${ }^{34}$ Kulkarni M. Initial Development and Validation of the Assessment of Beliefs and Behaviors in Coping (ABC). Dissertation. The University of Texas at Austin, 2012. 158 p. 
According to the self-determination theory we adapted and modified questionnaire aimed at religious self-regulation. The first task of the study involves the standardization of the questionnaire, in particular, its reliability, constructive, discriminatory and convergent validity, and test-retest reliability.

Reliability of the questionnaire. The first step in processing the raw data received was to check the internal consistency of the questionnaire. The Cronbach's alpha statistics were calculated for a scale that includes all 37 items. The value of the Cronbach's alpha for a scale of 37 items was 0,621 , which is below the acceptable level of 0,7 .

According to the results of the analysis of the indicators of Cronbach's alpha for the each item of the questionnaire it was established that the $10^{\text {th }}$ "An important reason why I attend church is because others would disapprove of me if I didn't», the 13th «The church is most important to me as a place to share fellowship with other Christians», the 14th «I pray at home because it helps me to be aware of God's presence», the $18^{\text {th }}$ «I allow almost nothing to prevent me from going to church on Sundays», the $21^{\text {st }}$ «What prayer offers me most is comfort when sorrow or misfortune strike», the $26^{\text {th }}$ "One reason for me praying is that it helps me to gain relief and protection» worsen the psychometric index of reliability. In addition, for these points, the values of asymmetry and excess indicate a significant deviation from the normality of distribution. These items are not highly differentiated and can be excluded from the final version of the questionnaire. Removing these items led to an increase the Cronbach's alpha to 0,703 , which is acceptable for internal consistency of the questionnaire. After this procedure, it was determined that the $31^{\text {th }}$ item «As I grow and change, I expect my religion to grow and change as well» also worsens the reliability of the questionnaire, and its deletion led to an increase of the Cronbach's alpha to a 0,714 .

Constructive validity of the questionnaire. The factor analysis was used to detect the internal structure of the questionnaire, excluding the items 10,13,14, 18, 21, 26 and 31. As a result of explorative factor analysis (with angular rotation) four factors that were not correlated with each other $(0,009-0,018)$ were found.

Factor 1 (18,61\% of dispersion) created by the items: the 15 th « My religious beliefs really shape my whole approach to life» $(0,797)$, the 11 th « I try hard to carry my religion over into all my other dealings in 
life» $(0,765)$, the $2 \mathrm{~d}$ «When I turn to God, I most often do it because I enjoy spending time with Him» $(0,751)$, the $3 \mathrm{~d}$ "When I turn to God, I most often do it because I find it is satisfying to me» $(0,733)$, the 4 th «A reason I think praying by myself is important is because I enjoy praying » $(0,672)$, the $12^{\text {th }}$ «I pray chiefly because it deepens my relationship with God» $(0,531)$, the $17^{\text {th }}$ «I go to church because it helps me to feel close to God», the $16^{\text {th }}$ «I often read books about prayers and the spiritual life». The statements of this factor indicate that it can be designated as a factor of the intrinsic religious motivation.

Factor 2 (15,77\% of dispersion) includes items: the $37^{\text {th }}$ «Religion only became very important for me when I began to ask questions» $(0,701)$, the $36^{\text {th }}$ «Questions are more important to my religious faith than are answers» $(0,641)$, the 33 th «I was driven to ask religious questions by a growing awareness of the tensions in my world» $(0,634)$, the $32 \mathrm{~d}$ «For me doubting is an important part of what it means to be religious» $(0,552)$, the $30^{\text {th }}$ «I am constantly questioning my religious beliefs» $(0,541), 34^{\text {th }}$ «I value my religious doubts and uncertainties» $(0,459)$, the $29^{\text {th }}$ «There are many religious issues on which my views are still changing». The psychological content of the points that formed this factor reflects the quest religious motivation.

Factor 3 (12,34\% of dispersion) presented by the following items: the $20^{\text {th }}$ «A key reason for my interest in church is that it is a pleasant social activity» $(0,715)$, the $23 \mathrm{~d}$ "One reason for me going to church is that it helps to establish me in the community» $(0,648)$, the $24^{\text {th }}$ «Occasionally I compromise my religious beliefs to protect my social and economic wellbeing» $(0,613)$, the $25^{\text {th }}$ «While I believe in my religion, there are more important things in my life» $(0,508)$, the $28^{\text {th }}$ «While I am a religious person I do not let religion influence my daily life» $(0,485)$. The psychological content of the statements that formed this factor reflects an external regulation.

Factor 4 (10,78\% of dispersion) combined the following items: the 7 th «One reason I think it's important to actively share my faith with others is because I want other Christians to approve of me» $(0,676)$, the 8 «When I turn to God, I most often do it because I would feel guilty if I didn't» $(0,553)$, the $22 \mathrm{~d}$ «I pray chiefly because it makes me feel better» $(0,531)$, the $9^{\text {th }}$ «A reason I think praying by myself is important is Because if I don't, God will disapprove of me» $(0,507)$. The 
psychological content of the points that formed this factor reflects the introjected regulation.

Factor 5 (9,83\% of dispersion) combined the following items: the 1 st «I think it's important to actively share my faith with others is because God is important to me and I'd like other people to know about Him too» $(0,576)$, the $5^{\text {th }}$ «A reason I think praying by myself is important is because I find prayer satisfying» $(0,543)$, the $6^{\text {th }}$ «An important reason why I attend church is by going to church I learn new things» $(0,521)$, the $19^{\text {th }}$ «My religious beliefs really shape the way I treat other people» $(0,512)$. The psychological content of the points that formed this factor reflects the identified regulation.

Thus, the final version of the questionnaire «Self-regulationion of labor activity Questionnaire» represented by scales - intrinsic motivation, quest motivation, identification, introjected regulation, external regulation. The developed technique meets the modern requirements for psychometric substantiation of personal questionnaires.

Test-retest reliability of the questionnaire. Repeated testing of the same sample (120 people) was conducted at intervals of two weeks. The correlation between the results of the first and second tests was at the level of $\mathrm{r}=0,893$, which indicates a sufficiently high test-retest reliability of the questionnaire.

Normative scale. In table 1 the descriptive statistics of «Religious Self-regulation» are set. Dividing into three intervals the marginal values of the norm for the indicators of the Intrinsic motivation are 20-30 points, for the Quest orientation are 18-26 points, for the next two scales (Identification and Introjected regulation) - 8-17 points and for the last one - External regulation - 13-22 points.

Table 1

Descriptive statistics of «Religious Self-regulation Questionnaire»

\begin{tabular}{|l|c|c|c|c|}
\hline \multicolumn{1}{|c|}{ Indicators } & Mean & Min & Max & Std. dev \\
\hline Intrinsic motivation & 26,54 & 8 & 40 & 5,34 \\
\hline Quest orientation & 22,31 & 7 & 35 & 4,67 \\
\hline Identification & 13,42 & 4 & 20 & 4,78 \\
\hline Introjected regulation & 12,55 & 4 & 20 & 5,45 \\
\hline External regulation & 17,08 & 5 & 25 & 4,34 \\
\hline
\end{tabular}


Convergent and discriminant validity of «Religious Self-regulation Questionnaire» checked out by identifying the correlation between the indicators of religious self-regulation and the indicators of the irrational thinking and a pseudoscientific explanation of being, spiritual intelligence, religious copings (convergent validity), and individual religiousness (discriminant validity).

There are a positive correlations between religious self-regulation and an irrational thinking and a pseudoscientific explanation of being: between the indicators of internal motivation $(r=0,49, p<0,0001)$ and identification $(\mathrm{r}=0,65, \mathrm{p}<0,0001)$ and traditional religious faith. The resulting connection indicates the mutual dependence of interest in religion, religious identification and inclination to the traditional religious faith. There are also correlations between Quest orientation and belief in psi-ability $(\mathrm{r}=0,62, \mathrm{p}<0,0001)$ and belief in spiritualism $(\mathrm{r}=0,39, \mathrm{p}<0,0001)$. Thus, the states of complexity, doubt, tentativeness, and honesty in facing existential questions related to faith and religiosity correlate with belief in psi-ability as an ability of mind to create paranormal phenomena or to control them.

There is a positive correlation between religious self-regulation and spiritual intelligence: introjected regulation is negatively related to the transcendent component of the spiritual intelligence $(r=-0,18, p<0,001)$, and there is a positive correlation between Quest orientation and the moral component of spiritual intelligence $(r=0,41, p<0,0001)$. Thus, the transcendent component of the spiritual intelligence, which associated with spiritual experiences, states and experience at various levels (including religious), and open the way to higher stages of spiritual development, doesn't relate to the sense of shame associated with the performance of religious rites. The moral component of the spiritual intelligence, including a system of "virtuous" behavior, the higher values and meanings of life, the ability to love, compassion, friendliness, empathy, which is the basis of both secular and sacred spirituality stained, relates to the doubt, tentativeness, and honesty in facing existential questions related to faith and religiosity.

There is a positive correlation between the indicators of internal motivation $(\mathrm{r}=0,39, \mathrm{p}<0,0001)$ and identification $(\mathrm{r}=0,33, \mathrm{p}<0,0001)$ and the existential component of the spiritual intelligence. The existential component of spiritual intelligence as the ability to accept the challenges of life, to solve the problems of existential reality, the ability 
to search for vital senses, provided by such cognitive properties as objectivity and impartiality of thinking, insight and vision relates to the interest to religion and identification with their religion.

There are correlations between the indicators of internal motivation, quest motivation and identification and such religious copings as providing a worldview that makes sense of life $(r=0,57, r=0,45$ and $\mathrm{r}=0,34, \mathrm{p}<0,0001$ ), allowing for a personal relationship with a higher power ( $\mathrm{r}=0,43$ for the internal motivation), providing overall structure in everyday life $(r=0,17, r=0,15$ and $r=0,14, p<0,01)$. Thus, interest in religion, existential doubts and identification through religion relate to beneficial religious coping strategies. There is a positive correlation between the indicators of introjected regulation and offering a sense of community $(r=0,57, p<0,0001)$. An adoption of religious behaviors and values which is predominantly based on social pressures and associated with the seeking of approval from oneself and from others relates to the applying of religion in relationship.

There are significant correlations between the indicators of religious self-regulation and individual religiousness, except correlations between external motivation and external signs of religiousness $(r=0,16, p<0,01)$ and between quest motivation and gnoseological roots of religiousness and tendency to idealistic philosophy $(\mathrm{r}=0,15, \mathrm{p}<0,01)$. External religious regulation which is used to ensure security and solace, sociability and distraction, status and self-justification, relates to the penchant for religious rites without true faith. Quest motivation which implies doubts and existential questions relates to the desire to comprehend the faith, the tendency to idealism in the philosophical worldview.

\section{CONCLUSIONS}

The psychological problem of religious self-regulation's assessment seems of current interest in connection with the need to provide psychological well-being. Self-determination theory, which considers the internal and external ways of activity regulation can be applied to religious motivation. According to self-determination theory and C. Batson's approach to religiosity we consider five ways of religious activity regulation: an intrinsic self-regulation or motivation, which assumes the interest and enjoyment connected with religiosity, quest motivation, which considers religion as a source of truth, and an 
extrinsic regulation (identification, introjected and external regulation), which requires the external values of religiosity.

The results of the Religious Self-regulation Questionnaire's standardization have shown. Its validity and reliability were proved. The convergent validity was checked out by identifying the correlation between the indicators of religious self-regulation and the indicators of the irrational thinking and a pseudoscientific explanation of being, spiritual intelligence, religious copings. There are positive correlations between religious self-regulation and an irrational thinking and a pseudoscientific explanation of being: between the indicators of internal motivation and identification and traditional religious faith. There are also correlations between Quest orientation and belief in psi-ability and belief in spiritualism. There is a positive correlation between religious self-regulation and spiritual intelligence: introjected regulation is negatively related to the transcendent component of the spiritual intelligence, and there is a positive correlation between Quest orientation and the moral component of spiritual intelligence. There is a positive correlation between the indicators of internal motivation and identification and the existential component of the spiritual intelligence. There are correlations between the indicators of internal motivation, quest motivation and identification and such religious copings as providing a worldview that makes sense of life, allowing for a personal relationship with a higher power, providing overall structure in everyday life. There is a positive correlation between the indicators of introjected regulation and offering a sense of community.

The discriminant validity was checked out by identifying the correlation between the indicators of religious self-regulation and the indicators of the individual religiousness. There are significant correlations between the indicators of religious self-regulation and individual religiousness, except correlations between external motivation and external signs of religiousness and between quest motivation and gnoseological roots of religiousness and tendency to idealistic philosophy.

\section{SUMMARY}

The paper emphasize the connection of religious self-regulation's and psychological well-being. The study underlines the need of standardization of the religious self-regulation's assessment and shows 
its results. It was shown that self-determination theory, which considers the internal and external ways of activity regulation, can be applied to religious motivation. According to self-determination theory and C. Batson's approach to religiosity five ways of religious activity regulation (an intrinsic self-regulation or motivation, quest motivation, identification, introjected and external regulation) are defined. The results of the Religious Self-regulation Questionnaire's standardization have shown. Its validity and high reliability were proved. The convergent and discriminant validity were checked out by identifying the correlation between the indicators of religious self-regulation and the indicators of the irrational thinking and a pseudoscientific explanation of being, spiritual intelligence, religious copings, the individual religiousness.

\section{REFERENCES}

1. Головіна О. Ю. Застосування опитувальника «Духовний інтелект особистості у вивченні духовності людини. Вісник начіонального університету оборони Украӥни. Збірник наукових праць. К: НУОУ, 2015. 3(46). С. 64-68.

2. Григорьев Д. С. Адаптация и валидизация шкалы веры в паранормальное. Социальная психология и общество. 2015. 6, 2. C. $132-145$.

3. Мягков И. Ф., Щербатых Ю. В., Кравцова М. С. Тест «Психологический анализ уровня индивидуальной религиозности». Психологический журнал. 1996. 10, 6. С. 120-122.

4. Ano, G. G., Vasconcelles, E. B. Religious Coping and Psychological Adjustment to Stress: A Meta-Analysis. Journal of Clinical Psychology, 2005. 61. Pp. 461-480.

5. Allport, G. W. Religious context of prejudice. Journal for the Scientific Study of Religion, 1966. 5. Pp. 447-457.

6. Allport, G. W., Ross, J. M. Personal religious orientation and prejudice. Journal of Personality and Social Psychology, 1967. 5, pp. 432-443.

7. Batson, D. Religion and the Individual. New York: Oxford University Press, $1982.440 \mathrm{p}$.

8. Batson, C. D., Ventis, W. L. The religious experience: A social psychological perspective. New York: Oxford University Press. 1982. $368 \mathrm{p}$. 
9. Batson, C. D., Schoenrade, P. A., Ventis, W. L. Religion and the individual: A social psychological perspective. New York, NY: Oxford University Press, 1993. $440 \mathrm{p}$.

10. Emmons, R. A. Religion in the psychology of personality: An introduction. Journal of Personality, 1999. 67, pp. 873-888. doi:10.1111/1467-6494.00076

11. Francis, L. J. Introducing the New Indices of Religious Orientation (NIRO): Conceptualisation and measurement. Mental Health, Religion and Culture, 2007. 10, 585-602.

12. Hills, P., Francis, L. J., Argyle, M., Jackson, C. J. Primary Personality Trait Correlates of Religious Practice and Orientation. Personality and Individual Differences, 2004. 36. Pp. 61-73. http://dx.doi.org/10.1016/S0191-8869(03)00051-5

13. Hunt S.J. Handbook of Global Contemporary Christianity: Movements, Institutions, and Allegiance (Brill Handbooks on Contemporary Religion) 2016. Brill; Approx. XXXV, 426 p.

14. Hunter, B. D., \& Merrill, R. M. Religious Orientation and Health among Active Older Adults in the United States. Journal of Religion and Health, 2013. 52. Pp. 851-863. http://dx.doi.org/10.1007/s10943-011-9530-4

15. Kulkarni M. Initial Development and Validation of the Assessment of Beliefs and Behaviors in Coping (ABC). Dissertation. The University of Texas at Austin, 2012. 158 p.

16. Kuznetsov O.I. Psychodiagnostics of religious coping strategies Вісник ХНПУ ім. Г.С. Сковороди. Психологія. Харків: ХНПУ, 2017. 57. C. $132-140$.

17. McCullough, M. E., Willoughby, B.L.B. Religion, SelfRegulation, and Self-Control: Associations, Explanations, and Implications. Psychological Bulletin. 2009. 135, pp. 69-93. doi:10.1037/a0014213

18. Pace, S. Effects Of Intrinsic And Extrinsic Religiosity On Attitudes Toward Products: Empirical Evidence Of Value-Expressive And Social-Adjustive Functions. The Journal of Applied Business Research, 2014. 30(4). Pp. 1227-1238.

19. Pargament, K. I. (2002). The bitter and the sweet: An evaluation of the costs and benefits of religiousness. Psychological Inquiry, 2002. 13, pp. 168-181. doi:10.1207/S15327965PLI1303_02 
20. Ryan, R. M., Deci, E. L. Intrinsic and Extrinsic Motivations: Classic Definitions and New Directions. Contemporary Educational Psychology. 2000. 25. Pp. 54-67.

21. Ryan, R. M., Rigby, S., King, K. Two types of religious internalization and their relations to religious orientations and mental health. Journal of Personality and Social Psychology, 1993. 65, pp. 586-596. doi:10.1037/0022-3514.65.3.586

22. Sedikides, C. Why does religiosity persist? Personality and Social Psychology Review, 2010. 14, Pp. 3-6. doi:10.1177/ 1088868309352323

23. Smith, T. B., McCullough, M. E., Poll, J. Religiousness and depression: Evidence for a main effect and the moderating influence of stressful life events. Psychological Bulletin, 2003. 129. Pp. 614-636.

24. White R. W. Motivation reconsidered. Psychological Review. 1959. 56. Pp. 297-333.

25. Witter, R. A., Stock, W. A., Okun, M. A., Haring, M. J. Religion and subjective well-being in adulthood: A quantitative synthesis. Review of Religious Research, 1985. 26, pp. 332-342.

APPENDIX

\begin{tabular}{|c|l|c|c|}
\hline No & \multicolumn{1}{|c|}{ Statements } & $\begin{array}{c}\text { Original } \\
\text { scale }\end{array}$ & $\begin{array}{c}\text { Final } \\
\text { scale }\end{array}$ \\
\hline 1 & $\begin{array}{l}\text { I think it's important to actively share my } \\
\text { faith with others is because God is important } \\
\text { to me and I'd like other people to know about } \\
\text { Him too. }\end{array}$ & Id & Id \\
\hline 2 & $\begin{array}{l}\text { When I turn to God, I most often do it because } \\
\text { I enjoy spending time with Him. }\end{array}$ & Id & Int \\
\hline 3 & $\begin{array}{l}\text { When I turn to God, I most often do it because } \\
\text { I find it is satisfying to me. }\end{array}$ & Id & Int \\
\hline 4 & $\begin{array}{l}\text { A reason I think praying by myself is } \\
\text { important is because I enjoy praying. }\end{array}$ & Id & Int \\
\hline 5 & $\begin{array}{l}\text { A reason I think praying by myself is } \\
\text { important is because I find prayer satisfying. }\end{array}$ & Id & Id \\
\hline 6 & $\begin{array}{l}\text { An important reason why I attend church is by } \\
\text { going to church I learn new things. }\end{array}$ & Id & Id \\
\hline 7 & $\begin{array}{l}\text { One reason I think it's important to actively } \\
\text { share my faith with others is because I want } \\
\text { other Christians to approve of me. }\end{array}$ & Itrj & Itrj \\
\hline
\end{tabular}




\begin{tabular}{|c|c|c|c|}
\hline No & Statements & $\begin{array}{l}\text { Original } \\
\text { scale }\end{array}$ & $\begin{array}{l}\text { Final } \\
\text { scale }\end{array}$ \\
\hline 8 & $\begin{array}{l}\text { When I turn to God, I most often do it because } \\
\text { I would feel guilty if I didn't. }\end{array}$ & Itrj & Itrj \\
\hline 9 & $\begin{array}{l}\text { A reason I think praying by myself is } \\
\text { important is Because if I don't, God will } \\
\text { disapprove of me }\end{array}$ & Itrj & Itrj \\
\hline 10 & $\begin{array}{l}\text { An important reason why I attend church is } \\
\text { because others would disapprove of me if I } \\
\text { didn't. }\end{array}$ & Itrj & - \\
\hline 11 & $\begin{array}{l}\text { I try hard to carry my religion over into all my } \\
\text { other dealings in life }\end{array}$ & Int & Int \\
\hline 12 & $\begin{array}{l}\text { I pray chiefly because it deepens my } \\
\text { relationship with God. }\end{array}$ & Int & Int \\
\hline 13 & $\begin{array}{l}\text { The church is most important to me as a place } \\
\text { to share fellowship with other Christians. }\end{array}$ & Int & - \\
\hline 14 & $\begin{array}{l}\text { I pray at home because it helps me to be } \\
\text { aware of God's presence }\end{array}$ & Int & - \\
\hline 15 & $\begin{array}{l}\text { My religious beliefs really shape my whole } \\
\text { approach to life }\end{array}$ & Int & Int \\
\hline 16 & $\begin{array}{l}\text { I often read books about prayers and the } \\
\text { spiritual life }\end{array}$ & Int & Int \\
\hline 17 & $\begin{array}{l}\text { I go to church because it helps me to feel } \\
\text { close to God }\end{array}$ & Int & Int \\
\hline 18 & $\begin{array}{l}\text { I allow almost nothing to prevent me from } \\
\text { going to church on Sundays }\end{array}$ & Int & Int \\
\hline 19 & $\begin{array}{l}\text { My religious beliefs really shape the way I } \\
\text { treat other people }\end{array}$ & Int & Id \\
\hline 20 & $\begin{array}{l}\text { A key reason for my interest in church is that } \\
\text { it is a pleasant social activity. }\end{array}$ & Ex & Ex \\
\hline 21 & $\begin{array}{l}\text { What prayer offers me most is comfort when } \\
\text { sorrow or misfortune strike. }\end{array}$ & Ex & - \\
\hline 22 & I pray chiefly because it makes me feel better. & Ex & Itrj \\
\hline 23 & $\begin{array}{l}\text { One reason for me going to church is that it } \\
\text { helps to establish me in the community. }\end{array}$ & Ex & Ex \\
\hline 24 & $\begin{array}{l}\text { Occasionally I compromise my religious } \\
\text { beliefs to protect my social and economic } \\
\text { wellbeing. }\end{array}$ & Ex & Ex \\
\hline
\end{tabular}




\begin{tabular}{|c|l|c|c|}
\hline No & \multicolumn{1}{|c|}{ Statements } & $\begin{array}{c}\text { Original } \\
\text { scale }\end{array}$ & $\begin{array}{c}\text { Final } \\
\text { scale }\end{array}$ \\
\hline 25 & $\begin{array}{l}\text { While I believe in my religion, there are more } \\
\text { important things in my life. }\end{array}$ & Ex & Ex \\
\hline 26 & $\begin{array}{l}\text { One reason for me praying is that it helps me } \\
\text { to gain relief and protection. }\end{array}$ & Ex & - \\
\hline 27 & $\begin{array}{l}\text { I go to church because it helps me to feel at } \\
\text { home in my neighbourhood. }\end{array}$ & Ex & - \\
\hline 28 & $\begin{array}{l}\text { While I am a religious person I do not let } \\
\text { religion influence my daily life. }\end{array}$ & Ex & Extr \\
\hline 29 & $\begin{array}{l}\text { There are many religious issues on which my } \\
\text { views are still changing. }\end{array}$ & Q & Q \\
\hline 30 & $\begin{array}{l}\text { I am constantly questioning my religious } \\
\text { beliefs. }\end{array}$ & $\mathrm{Q}$ & $\mathrm{Q}$ \\
\hline 31 & $\begin{array}{l}\text { As I grow and change, I expect my religion to } \\
\text { grow and change as well. }\end{array}$ & $\mathrm{Q}$ & - \\
\hline 32 & $\begin{array}{l}\text { For me doubting is an important part of what } \\
\text { it means to be religious. }\end{array}$ & $\mathrm{Q}$ & $\mathrm{Q}$ \\
\hline 33 & $\begin{array}{l}\text { I was driven to ask religious questions by a } \\
\text { growing awareness of the tensions in my } \\
\text { world. }\end{array}$ & $\mathrm{Q}$ & - \\
\hline 34 & I value my religious doubts and uncertainties. & $\mathrm{Q}$ & $\mathrm{Q}$ \\
\hline 35 & $\begin{array}{l}\text { My life experiences have led me to rethink } \\
\text { my religious beliefs. }\end{array}$ & $\mathrm{Q}$ & - \\
\hline 36 & $\begin{array}{l}\text { Questions are more important to my religious } \\
\text { faith than are answers. }\end{array}$ & $\mathrm{Q}$ & $\mathrm{Q}$ \\
\hline 37 & $\begin{array}{l}\text { Religion only became very important for me } \\
\text { when I began to ask questions. }\end{array}$ & $\mathrm{Q}$ & $\mathrm{Q}$ \\
\hline
\end{tabular}

Information about the author:

Kuznetsov O. I.

Candidate of Psychology, Assistant Professor of the Department of Practical Psychology H.S. Skovoroda Kharkiv National Pedagogical University 29, Alchevskikh str., Kharkiv, 61002, Ukraine 